\title{
EXPERIMENTS IN TRANSPLANTING LIMBS AND THEIR BEARING UPON THE PROBLEMS OF THE DEVELOPMENT OF NERVES ${ }^{1}$
}

$\mathrm{BY}$

ROSS GRANVILLE HARRISON

With Fourteen Figures

Several years ago Braus described a series of ingenious experiments in transplanting limbs of amphibian (Bombinator) larvæ. The experiments were made mainly for the purpose of inquiring into questions relative to the development of peripheral nerves and their author has interpreted his results in accordance with Hensen's theory. Briefly stated this theory is that the nerve centers and their peripheral end-organs are connected from the beginning of embryonic life by means of protoplasmic bridges, and that the development of the nerve fiber consists merely in the differentiation of these pre-existing connections under the stimulus of functional activity. Banchi, whose results have, however, been contradicted by Gemelli, has also made transplantation experiments and like Braus has been led to the conclusion that the peripheral nerves develop in situ and that they may undergo their development even when not connected with ganglion cells. $\mathrm{My}_{\mathrm{y}}$ own experiments lend, on the other hand, no support whatever to the Hensen theory but show in agreement with His that the nerve fiber is the outgrowth of the ganglion cell. ${ }^{2}$ It is this difference of opinion that has led to the following study, which is

$1 \mathrm{~A}$ brief account of the experiments described below was given in a paper read before the Section in Anatomy of the British Medical Association at the meeting held in Toronto, August 21-25, 1906. The work was reported more fully to the Association of American Anatomists at the New York Meeting, December 29, 1906. See Anatomical Record, Am. Journ. Anat., vol. vi, no. 3 .

'Harrison '04a, 'o6.

The Jouryal of Experimental Zoölogy, vol. iv, no. 2. 
based upon a new series of experiments similar to those of Braus and Banchi. Before describing the new experiments it will be necessary to consider the previous work in detail, beginning with that of Braus, the main facts of which are as follows:

I If an extremity is taken at a time when it is beginning to develop and is transplanted to any region of another tadpole, it will continue its development in the new position and ultimately be found to contain all of the parts-muscles, skeleton, blood vessels and nerves-which are perfectly normal both as to structure and arrangement. The nerves are connected with the nerves supplying the region of the host into which the limb has been implanted, as, for instance, with the facial nerve when the limb is placed on the side of the head in the region of the orbitohyoid muscle, or with the nerves of the lumbo-sacral plexus when a fore limb is transplanted to the hind limb region. But the nerves within these transplanted extremities, in spite of their unusual origin, ramify exactly as the nerves in a limb in its natural position. Furthermore, these nerves are functional, both voluntary movements of the limbs and movements in response to electrical stimulation having been observed. In considering this experiment, Braus lays great stress upon the point that at the time of transplantation either there are no visibly differentiated nerves within the limb, ${ }^{3}$ or, if nerves are present, they degenerate and disappear very soon after; the latter was the case in his earlier experiments.

2 In a second series of experiments limb buds were taken from larvæ, from which the whole spinal cord had been removed at a period just after the closure of the medullary folds. Such embryos develop normally aside from the defect caused by the wound, but they contain no nerves except those arising in the head." Extremities taken from individuals of this character Braus terms "aneurogenic," in contradistinction to the normal ones which are called "euneurogenic." The aneurogenic buds were taken from the nerveless larvæ ten days after the removal of the spinal cord and implanted into the hind limb region of normal individuals. Eight days later these larvæ were preserved but, although the transplanted limbs had developed considerably, no nerves were found in them, whereas a normal or euneurogenic transplanted bud would have contained nerves by this time.

3 The normal transplanted limbs acquire, as stated above, nerves which take a normal course. Examination of such limbs in a state of incomplete development, for example, about three weeks after transplantation, shows that the nerve trunks within them are much thicker than the nerves of the host with which they are connected.

BBraus '05, p. $43^{8}$.

4 Harrison'o4. 
4 It happens not infrequently that the transplanted extremity does not remain single, but gives rise to a second limb which is the mirror image of the original one. This accessory limb is at first small but after a time may overtake the original one in development. Such supernumerary limbs may also be formed after irregular amputations or mutilation of the limb rudiment in normal tadpoles, ${ }^{5}$ in which case the nerves as well as the other structures are typically developed. On the other hand, when the supernumerary limb develops from a transplanted bud, Braus finds that nerves are totally lacking within it, as indicated both histologically and by the failure of such limbs to respond to electrical stimulation.

Aside from these main points Braus' papers contain a wealth of interesting and important observations. His conclusions are however, interwoven with his statements of fact and are presented in the form of a continuous argument, thus rendering it difficult to bring effective criticism to bear upon the work. Nevertheless, by first admitting the facts to be true, we may take up the thread of the argument and, I think, conclusively show that it does not constitute a logical proof of the continuity theory, but is merely to be regarded as a possible interpretation, in which analogies and collateral facts of uncertain relevance play a large rôle. The same facts may be interpreted quite as readily, if not more so, in accordance with the outgrowth theory. The experiments do not approach the problem directly enough to determine questions of histogenesis, and there are too many loopholes left to permit of a rigid proof. In the experimental part of the present paper it will be further shown that the facts which are most important for Braus' argument are not of general validity.

In considering the experiments just referred to under the first heading, Braus attacks the question as to the origin of the nerves in the transplanted limbs. ${ }^{\circ}$ Are the nerves developed out of struc-

${ }^{5}$ Barfurth '94; Tornier' 05.

"Braus states this problem in somewhat different form: "Um dies zu erläntern, möchte ich zunächst die Frage zu beantworten versuchen: an welcher Stelle verbindet sich bei meinen Kompositionen die motorische Bahn des Autositen mit derjenigen des Parasiten?

* * * Es müsste deshalb auf der ganzen Ausdehnung der motorischen Bahn nach der Verwachsungsstelle gesucht werden; doch kommen naturgemäss auf dieser 3 stellen hauptsächlich in Betracht: (I) die Stelle, an welcher die peripheren Nerven mit den Muskeln der transplantierten Gliedmasse in Verbindung stehen, d. h. also innerhalb des Parasiten; (2) die Stelle, an welcher die Einpfropfung erfolgte und wo primär bei der Operation die Gewebe der beiden verwendeten Emb̀ryonen 
tures already present in the limb at the time of transplantation, or do they grow into the limb from the nerves of the host, guided to their proper place by the structures within the limb? Obviously the experiment under consideration is not, in itself, sufficient to dispose of the question, though Braus contends, that when we clearly analyze the meaning of the one central fact, that the transplanted limb contains a typically arranged nervous system, the first of the three possibilities stated by him, i.e., the formation of the nerves by outgrowth from the center, is to be excluded.

The results of nerve suturing are dismissed as having no bearing on the case, on the ground that there are no nerves present in the limb at the time of transplantation to serve as guide-lines for possible outgrowing nerves. In making this point, however, Braus has failed to note that in normal embryos the nerves reach the immediate vicinity of both the fore and hind limb buds before these appendages are distinguishable. ${ }^{7}$ It would, therefore, be impossible to remove a limb bud-and this is especially true of the fore limb (Fig. 1), which Braus used in the majority of his experiments-without including the finer terminal nerve twigs. It would also be impossible to make the incision for implantation without cutting some nerves of the host. Thus in grafting a normal limb upon a normal larva we cannot avoid bringing the cut ends of the nerves of the latter into close proximity to the isolated nerve twigs contained within the former. The two are not actually sutured together, but as Forssmann has shown conclusively, degenerating nervous tissue attracts from a distance the nerve fibers arising from a cut nerve, ${ }^{8}$ and the distances in the embryonic transplantations under consideration are sufficiently minute to fall well within this limit. We must therefore consider that also in these embryonic transplantations guiding nerve twigs may be present, though even were they totally lacking in the transplanted bud, the nerves of the host would be brought into close

aneinander geheilt wurden, d. h. also innerhalb der Vereinigungsstelle des Parasiten und Autositen; (3) die Stelle, an welcher das periphere Nervensystem mit dem zentralen, speziell den motorischen Ganglienzellen des letzteren zusammenhängt, d. h. also innerhalb des Autositen." Braus '05, p. 44z. ${ }^{7}$ See p. 253 .

${ }^{8}$ Forssmann '98, 'so. 
proximity with the latter, while it is still nothing but a small nodule of mesenchyme cells, and there is no reason to suppose that these nerves would have any more difficulty in making proper connections, than the nerves have in growing into the natural limbs. It would therefore seem to be almost immaterial from the standpoint of the outgrowth theory whether nerve twigs are present in the limb at the time of transplantation or not, and my own experiments show that this is actually the case. ${ }^{9}$

Braus nevertheless finds an insuperable objection to the acceptance of the outgrowth theory in the fact that the grafted limb is entirely new territory for the nerve, where we should not be justified in supposing the latter to be able to find its way. But this difficulty would be real, only in case it could be shown that the nerve fibers going to each organ are specific, $i . e$., that the mode of branching of the fibers is determined in the nerves themselves.. While it may be true that there are some specific differences between, for example, muscular and cutaneous nerve fibers, there is no evidence to show that the nerves running to any particular muscle are different from those supplying other muscles. In fact our experience with nerve anastomosis shows that the contrary is the case. There is no difficulty, therefore, in the supposition that, if the structures in the fore limb normally direct the course of the nerves of the brachial plexus, they may direct equally well the lumbo-sacral nerves, when, as in the case of the transplantations, the fore limb is placed in the way of t.:e latter.

Braus supports his contention mainly upon the supposed analogy with the behavior of the rudiment of the lateral line organs in development, but in so doing he has partially mistaken the meaning of my experiments which he cites. ${ }^{10}$ While these experiments did show that the rudiment of the sense organs-the nerve itself is merely drawn along with them-does not grow except in normal paths or paths similar to the normal ones, they did not prove that the vagus organs, for instance, could not grow into the supra-orbital path, as would have to be the case were the analogy with the strange nerves in a transplanted limb to hold. In

${ }^{2}$ See pp. $25^{6}$ and 269.

${ }^{\mathrm{T}}$ Harrison 'o3. 
fact my experiments did actually show ${ }^{11}$ that the main chain of organs would grow into the path of the dorsal branch when the former was shifted from its normal course, just as we may suppose the nerves of the lumbo-sacral region to grow under the guidance of the paths in the forelimb. Thus the analogy favors the possibility of outgrowth into strange paths and not the opposite as Braus supposes.

We now come to the second main point made by Braus, which is that an "aneurogenic" extremity when transplanted to a normal individual does not acquire a nervous system. Were the nerves formed as outgrowths from the nerves of the host, Braus argues that they should grow just as readily into "aneurogenic" extremities as into the normal ones. ${ }^{12}$ Their failure to do so he regards as sufficient ground for rejecting the outgrowth theory. ${ }^{13}$ It is true one may interpret this result in accordance with Hensen's theory, though in so doing it must be admitted that the differentiation of the nerve fibers is dependent upon the integrity of their connection with the centers, for the only reason to be given that the nerves have not been formed in the aneurogenic buds at the time of transplantation is because their connection with the centers have been destroyed; not having been in connection during the critical period, their development at any future period is precluded and such limbs remain therefore without nerves. But it is not necessary to refer differences between the "aneurogenic" and the "euneurogenic" extremities to invisible pre-nervous structures for, as already mentioned, there are actual visible nerve fibers present in the normal or "euneurogenic" buds at the time of transplantation, while, of course, in the "aneurogenic" ones there are none. ${ }^{14}$ But even this tangible difference between the two sorts of limb buds does not actually cause the nerves to behave differently toward them, unless, possibly, the absence of the nerve twigs in the one case retards to a slight extent the development of the nerves, for, as my

"Op. cit., p. 127 .

12Braus '05, p. $45^{\circ}$.

${ }^{13}$ Braus '05, p. 452.

${ }^{14}$ This was given as a possible explanation in my brief criticism of Braus' work (Harrison 'o6). At that time I did not have the data afforded by my own experiments, which show that as a matter of fact no explanation is necessary. 
own experiments show, contrary to those of Braus, a normally arranged nervous system does usually develop in the "aneurogenic" extremities.

The third point which Braus makes is, that while the nerves which connect transplanted limbs with the central nervous system of the host are extremely minute, those within the limb are almost as thick as the nerves in the normallimb. As Braus points out, there are obviously two possible arrangements which may account for this condition; either there are some fibers in the transplanted limb that are not connected with nerve fibers of the host, or the fibers connecting with the host branch frequently as they enter the grafted appendage. Since it has not been possible to determine by direct observation which of these alternatives is true, Braus has attempted to settle the question indirectly. He is led to reject the latter alternative and in accepting the former concludes that the fibers in the grafted leg are developed autochthonously. The first consideration which Braus adduces against the idea of division is that the number of neuro-fibrils in the peripheral part of the nerve is much greater than in the connecting strands, and since according to Apáthy the fibrils in peripheral nerve tibers do not bifurcate, the peripheral increase cannot possibly be accounted for in this way. 'This, to say the least, is an extremely, hazardous conclusion to draw, for it has never been shown with any degree of certainty that the fibrils do not divide in the axones of vertebrates. In fact there is now considerable positive evidence that branching does take place. Dogiel has shown this to be the case in the nerves running to the corpuscles of Herbst and Grandry, and Ramon y Cajal in certain cortical axones. Retzius has demonstrated that the fibrille increase in number on either side of the nodes of Ranvier and quite recently Schiefferdecker has confirmed and extended this observation, showing that in peripheral nerves of the frog finer fibrils coalesce at the nodes of Ranvier into a small number of much coarser threads, which, after the node is passed again break up into the finer fibrillæ. In other words the neurofibrils of a peripheral nerve form a network. ${ }^{15}$

\footnotetext{
${ }^{15}$ Schiefferdecker ('o6a) discusses at length the relations and mode of branching of the fibrilla both in the cell body and in the axis cylinder.
} 
In view of these facts the observation of an increase in the number of fibrillæ in a given peripheral nerve as its end is approached can have no weight in support of the hypothesis that some of them are lacking connection with the center. ${ }^{18}$

There is another consideration which Braus takes up in support of his explanation of the greater thickness of the nerves within the transplanted extremity. He says, if one follows the development of the specimens until the nerves become myelinated, one finds on counting the fibers that there are now no more within the transplanted limb than in the connecting nerves. This shows, it is maintained, that, of the numerous fibers in the transplanted limbs after metamorphosis, when its functional activity comes into consideration, only those which are connected with fibers in the host get myelin sheaths; the superfluous fibrillæ supposedly disintegrate. It would require study of a large number of instances to prove that this change in the numerical relation between the intrinsic and extrinsic nerve fibers of the limb during the course of development is of general occurrence; yet the establishment of this fact would give us only one of the necessary premises requisite to put Braus' conclusion upon a logical basis. Braus does not mention the exact number of cases studied, but actual figures are given in only a single instance. Now the relation of the size of the nerve trunks within the limb to that of the connecting nerves of the host, is very variable, as my own cases show, and hence it is quite within the bounds of possibility, not to speak of proba-

\footnotetext{
${ }^{16}$ Curiously enough Braus calls to the support of his view the conditions found in the nerve to the electric organ of Malapterurus, where, as is well known, the organ of each side is innervated by a single large cell. Since the single fiber derived from this cell ultimately breaks up into several million twigs, one would naturally suppose that this would show pretty conclusively that the fibrils must branch. As a matter of fact it does, but Braus in maintaining the contrary is misled by the fact that the main nerve is described as of very large caliber. The actual figures given by Fritsch show at once the untenability of Braus' position. While the nerve is as a matter of fact enormous, having a diameter of $\mathrm{r}, \mathrm{I} \mathrm{mm}$., its thickness is accounted for by its sheaths. The axis cylinder is but $8 \mu$ in diameter. There are estimated to be $2,171,252$ electric discs in the organ, each of which receives a nerve, the combined area of cross section of the terminal stalks being 346,760 times the area of cross section of the original fiber. Assuming each terminal twig to contain but a single fibril, though probably there are more, and that there is no branching, the main axis cylinder would have to contain at least $2,171,252$ fibrilla, which is of course an absurdity, for in order that so many be squeezed into such small compass the individual fibril, even allowing no space at all for interfibrillar substance, could not be more than about $.005 \mu$ thick, which is far below the range of visibility.
} 
bility, that in the case which Braus cites the relative size of the different parts of the nerve trunk was the same in the earlier stages of development as when finally enumerated. I have not found in any of my experiments such marked differences in size between the intrinsic and extrinsic portions of the nerves as Braus found in the case figured ${ }^{17}$ and there may even be no enlargement at all. Furthermore, sudden thickening of the nerve trunks do not take place exclusively at the point where they enter the limb but may take place at any dividing point within the limb.

In this connection it is interesting to note that the exact enumeration of the nerve fibers in the hind legs of adult frogs, made by Dunn, shows that the number of medullated fibers increases as the periphery is approached. ${ }^{18}$ This increase is not confined to the finer nerve twigs but begins to manifest itself in the sciatic nerve where Dunn finds that the increase is from 6 to 8 per cent. This is due to bifurcation of fibers; branching fibers of large caliber were actually observed in teased preparations. When, therefore, we explain the peripheral enlargement of the nerves as they enter the transplanted extremities as due to division of the axones and not, as Braus holds, to the existence of fibers having no connection with the center, we are calling into consideration a condition which differs from the normal merely in degree, not in kind. This view is, in other words, in accordance with known facts relating to the peripheral distribution of nerves, while the explanation given by Braus can at best be regarded as an uncertain hypothesis.

The fourth point which Braus makes is of somewhat the same nature as the second, and is considered by him as showing that the origin of the nerve fibers is to be sought in a much earlier stage of development than that in which either the cell outgrowth theory or the cell chain theory of Balfour place it. ${ }^{10}$ It is maintained that no nerves are formed in the accessory limbs which often arise from the transplanted buds, and that this is a distinct confirmation of the argument against the outgrowth theory, because this

\footnotetext{
"Braus' 05, Fig. 12A, p. 454.

18This was pointed out by Professor Donaldson in the discussion which followed the realing of my communication before the British Medical Association.

${ }^{19}$ Braus 'o5, p. 460.
} 
theory is unable to explain why the nerves do not grow into the accessory as well as into the primary limb. In reply to this, it may be pointed out that while it might be difficult to explain why the nerves never grow into such limbs, there is nevertheless a very natural explanation, not considered by Braus, why they might often be easily overlooked. This explanation is based upon the fact given by Braus that the nerve trunks in transplanted limbs contain only a small fraction of the fibers found in a normal limb. When the secondary limb buds out, it derives its nerves, therefore, from a very much attenuated nervous system, and of course it receives only a very small fraction of the fibers making up the latter. Supposing, for example, that the transplanted bud receives but one-tenth of the normal number of fibers and the accessory bud but one-tenth of these, then the latter would receive but one hundredth part of the normal number, which would render the nerves so minute that they might escape observation. This actually happened in one of my cases when the sections were gone over the first time, though afterward the much attenuated nerves were observed and found to be fairly complete. In other cases, both in accessory limbs derived from "aneurogenic" buds and in those from normal buds, the nervous system was well developed. These facts show that while Braus' statement regarding the absence of nerves from the accessory limbs may hold true in particular cases, as a generalization it is incorrect.

In reviewing the above considerations, it may be fairly said that there are no facts brought out in Braus' contributions which cannot be interpreted in an unforced way in accordance with the view that the nerve fiber is the outgrowth of the ganglion cell. It is not contended that the facts prove the truth of this conception, but merely that they do not antagonize it. When, on the other hand, they are interpreted in the light of Hensen's theory, Braus finds it necessary to make a number of subsidiary assumptions which are not always consistent with one another. I may refer especially to the position which is taken regarding the formative influence of the nerve center upon the developing fiber. Thus in explaining the difference between the "aneurogenic" and "euneurogenic" limb buds, Braus supposes that a connection with the center is necessary in the 
early stages of development in order that the nerve fibers may afterward differentiate; then to explain the greater thickness of the intrinsic nerves of the transplanted limb in comparison with the connecting nerves within the body of the host, it is assumed that nerve fibers may develop autochthonously within the limb without having any connection with the nerve centers; finally to account for the reduction of the number of fibers within the transplanted limbs after myelinization sets and the muscles become functional, the connection with the center is again supposed to be necessary. A change of this kind in the necessary conditions governing the well-being of the nerve fiber is, on its face, extremely improbable and any theory requiring such inconsistent assumptions for its support, as the Hensen theory seems to require in this case, must be regarded as altogether unsatisfactory.

We may now pass to the consideration of the work of Banchi, who claims to have found within transplanted limbs nerves which had no connection whatever with the nerves of the host. Banchi's method of procedure is somewhat different from that of Braus, one difference being that younger embryos were used for the experiments. It is, however, an error to maintain that the pieces transplanted contain no traces of vessels or nerves, ${ }^{20}$ for spinal nerves reach at the stage in question the primary abdominal muscle, which skirts the hind limb rudiment and which Banchi shows in his figure. These nerves may be readily observed in well stained sections, though it is necessary to use high powers of magnification to bring them out clearly. They may also be readily demonstrated in preparations of the abdominal walls in toto. What Banchi has gained over Braus by operating on earlier stages he has lost in using such extensive pieces. It is probable that the pieces which the former transplants contain more nerve fibers and Schwann cells than those of which Braus has made use of. When we examine Banchi's experiments we find that out of twenty-nine cases which are described there are only two in which the transplanted limbs contain nerves purporting to have no connection

\footnotetext{
${ }^{20}$ This is maintained in one place though in the conclusion the statement is ccnsiderably modified. Cf. Banchi '05, pp. 675 and 689 .
} 
with the nerves of the host. In three other cases the nerves which were found were connected with the nerves of the host. With reference to the other twenty-four the author does not mention nerves except in two cases, in which, it is stated, the relations of the nerves could not be made out.

In a later paper Banchi gives an account of some further experiments, in which specimens were preserved for examination at various intervals after the operation, beginning at six days. The pieces transplanted were not limb buds but pieces of the side of the body, including parts of myotomes and notochord and also, as Banchi admits, portions of spinal nerves. Examined later, it is maintained that in some cases well developed nerves may be found which contain no traces of ganglion cells and have no connection with the nerves of the host. Banchi concludes from these experiments that the nerves are of pluricellular origin and that they may differentiate when cut off from the center. Banchi then points out that what he has found in the field of development corresponds to what Bethe has found in the field of regeneration.

These last experiments cannot be regarded as any more conclusive than the first. It must not be lost sight of that Banchi has really transplanted nerves already partially differentiated; at best he has shown that these nerves are able to continue their existence and perhaps grow a little after being cut off from their ganglion cells. But the experiments do not even prove this, for the pieces were transplanted to other embryos which are teeming with nerves, and in such cases there is always the possibility, or even the probability that connections with the nerves of the host were present but overlooked. The small number of cases purporting to give positive results lends strength to this view. As Braus has shown, the connecting nerves may be very much thinner than the nerves in the grafted piece itself, and it is not difficult to overlook nerves of considerable size, unless one carefully examines the series of sections with an oil immersion lens.

Gemelli's results contradict Banchi's directly and are of special importance because some of the actual steps by which the ingrowth of the nerves into the transplanted tissue were observed. Specimens were killed at short intervals beginning the second day after 
operation. After the fourth day Gemelli was in all cases able to detect nerve filaments which arose from the nerves of the host and extended toward the grafted appendage; in somewhat later stages it was found that these nerves entered the latter and that they in all cases preserved their connection with the nerves of the host.

When, therefore, we consider that Braus, Gemelli and myself have never found cases in which the nerves of the transplanted limb were not connected with the nerves of the host, and also that Banchi himself claims to have found only a small proportion of cases in which no connection could be traced; and further, when we consider that a ready source of contamination was present, and that small nerves in the embryonic body may easily elude observation, we cannot but conclude that Banchi is in error in the interpretation of his material, and that there is as yet no satisfactory proof for the claim that nerves may differentiate in a peripheral part when nervous connection with the center does not exist. ${ }^{21}$ In order to prove definitely this important proposition, it is necessary that every possible precaution be taken to prevent the formation of anastomoses. The experiments upon which the present claims in favor of the autogenetic development of nerve fibers are based do not measure up to this standard, and the position of those who are now advocating this view on the strength of these experiments, in which sources of contamination were not eliminated, presents a strong resemblance to the position formerly taken by the advocates of abiogenesis, while in fact there is no more evidence for the one than for the other.

\section{EXPERIMENTS}

The experiments, consisting of two series, which are to be described below, were made upon larvæ of Rana sylvatica and Bufo lentiginosus.

In the first series limb buds taken from nerveless or "aneurogenic" larvæ were transplanted to normal individuals. The nerveless specimens were produced, as described previously, ${ }^{22}$ by

\footnotetext{
${ }^{21}$ The question of autoregeneration of fully differentiated nerves is here left out of consideration, the writer reserving his opinion on this matter.

${ }^{22}$ Harrison '04, p. 20 .
} 
cutting off from the dorsal edge of the body of the embryo at a stage when the medullary folds had just closed, a thin strip containing the spinal cord. At the time of this operation no visible differentiation of fibers had taken place either within the central nervous system or without, and the specimens passed through their further development in the entire absence of peripheral nerves except those derived from the head region, which had not been injured. They lived and developed normally until the yolk absorp-

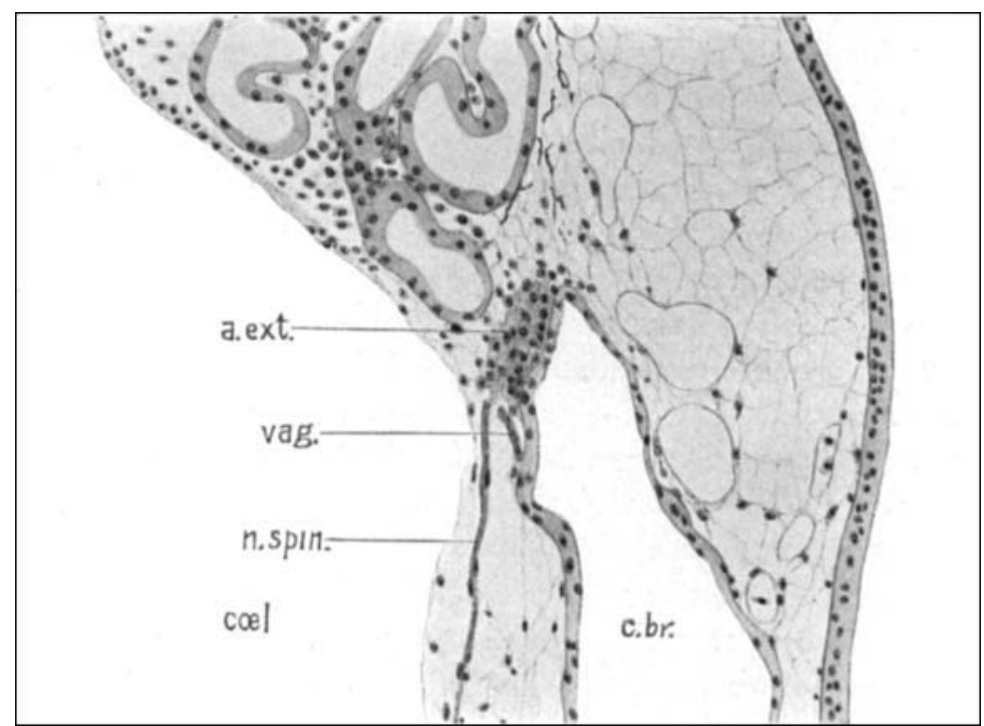

Fig. I Cross section through the pronephric region of an embryo of Rana palustris $12 \mathrm{~mm}$. long, in which the absorption of the yolk is almost complete. a. ext., fore limb; vag., abdominal branch of the r. lateralis vagi; $n$. spin., ramus abdominalis n. spinalis; cel.. body cavity; $c . b r_{.}$, branchial cavity. $\times_{1} 33$.

tion was complete or nearly so, a period varying with the temperature from seven to nine days. ${ }^{23}$ At the end of this time the hind limb buds were transplanted to normal larvæ of the same age.

${ }^{23}$ Braus transplanted the nerveless limbs ten days after the removal of the spinal cord. The shorter period of time represented in my experiments does not mean that the embryos had developed less than those used by Braus but simply that they had probably developed at a higher temperature. It was deemed unwise to keep them longer, for degenerative changes are very rapid after the yolk is absorbed, and death soon follows. 
These experiments were controlled by transplanting normal hindlimbs, to the same individuals that had received the nerveless buds, the latter having been placed on the right side of the trunk, the former on the left.

At this period of development the rudiments of both the fore and hind limbs are little knobs or buds which project slightly from the surface of the body, the fore limb being concealed, however, by the operculum. Each of the limbs consists of a group of mesenchyme cells situated in the body wall between the somatopleuric

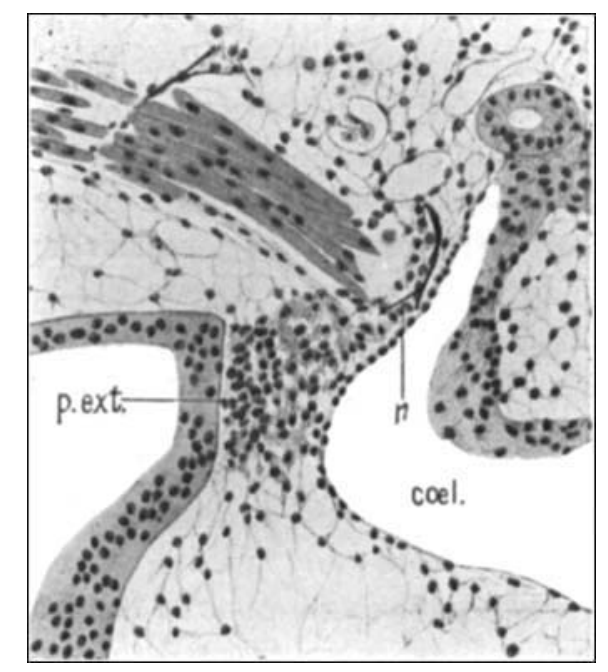

Fig. 2 Sagittal section through the hind limb region of a larva of Rana palustris in mm. long slightly younger than the embryo from which Fig. I was taken. p. ext., hind limb; cal., coelom; $n$, nerve reaching nearly to base of limb. $X_{133}$.

mesoderm and the epidermis. The cells at this period are closely crowded (Figs. I and 2), but as yet no differentiation of tissues is noticeable. There is no visible difference between the limbs in the normal and nerveless individuals except in respect to the nerve fibers, which either run to or skirt past the base of the normal ones. In this respect my own observations cannot be brought into accord with those of Braus, who denies the presence of nerves in the normal limbs at this time. A careful study of numerous series of sec- 
tions of Rana embryos in closely graded developmental stages will convince one that nerves are present in the immediate vicinity of both the fore and hind limbs as soon as the limbs themselves become distinguishable, and in the case of the fore limb (Fig. I), even before any signs of the mesenchymatic thickening can be made out.

The specimens were kept alive for a considerable length of time, in most cases until the hind limbs, both natural and transplanted, were fairly well developed and showed the various articulations. In this respect my own experiments differed from those of Braus, who kept none of his "aneurogenic" transplantations alive longer than eight days. It is quite probable that this difference would be sufficient to account for the divergence of our results.

In the second series of experiments, which were made to test the power of autochthonous development of peripheral nerves, normal hind limb buds were transplanted to nerveless organisms. Braus recognized the importance of this experiment and attempted to carry it out, though without results, for the reason that the nerveless tadpoles were unable to maintain themselves alive for a sufficient length of time. This difficulty was obviated in the present case by providing each nerveless individual with a nurse, $i$. e., by uniting it to a normal larva, in the fashion of Siamese twins (Fig. I4). The experiments were only partially successful, however, because for some unknown reason none of the transplanted limbs grew well on the bodies of these nerveless larvæ.

\section{Transplantation of Normal and Nerveless Limbs to Normal Individuals}

The four experiments to be considered under this heading will be taken up individually.

Experiment $I^{24}$ The three larvæ (R. sylvatica) used for this experiment were reared together under the same external conditions. On April I 5, rgo6, shortly after the medullary folds had closed over, the medullary cord behind the vagus region was entirely removed from one specimen. On April 22, the absorption of the 
yolk being nearly complete, the transplantation of the limbs was undertaken. During the intervening period the normal specimens had developed a little more rapidly than the nerveless one, the external form of which is shown in Fig. 3. The limb buds were transplanted to the side of the body of one of the normal individuals, dorsal and anterior to its natural hind limbs, the right limb from the nerveless individual being placed on the right and the left limb of the normal one on the left.

After removal of the hind limb for the purpose of transplantation the nerveless larva was preserved and afterward cut into sections. It was found that the operation for the removal of the spinal cord had been entirely successful. The central nervous system ends abruptly immediately behind the auditory vesicle and no ganglion cells are to be found posterior to the vagus. The brain has undergone marked histolytic changes, practically no

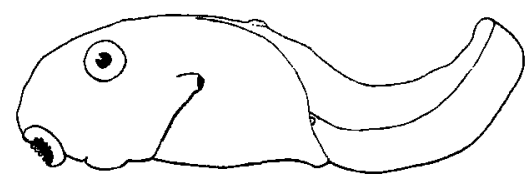

Fig. 3 Embrvo from which the nerveless limb in Experiment I was taken. $\times 9$.

normal nerve cells being left in it. No longitudinal bundle fibers have grown out posteriorly from the brain and there are no signs of regeneration. The only nerves to be found in the body are those arising in the head. It is therefore certain that the limb transplanted from this individual was entirely nerveless.

The tadpole was kept alive until May 22, during which time it grew rapidly and both of the transplanted limbs as well as the normal ones developed well. Each one of the transplanted buds gave rise to a pair of legs, as Braus described in some of his cases. The photograph (Fig. 4), which was taken after the specimen was preserved, shows the "aneurogenic" or "nerveless" extremities in addition to the natural ones. The thigh which projects dorsally is part of the primary limb, a right hind leg, while the other leg, a left, which projects directly caudalward, is the accessory one. ${ }^{25}$

\footnotetext{
${ }^{25}$ Tornier and Braus have shown that the accessoty limb is the mirror image of the primary one from which it is budded.
} 
The larva was closely observed while alive, and it was noted that slight movements took place in the "aneurogenic" limb. No attempt was made to stimulate electrically, but the spontaneous movements, though very slight, were unmistakable.

After preservation in Zenker's fluid the specimen was cut into serial transverse sections, and the internal anatomy of the extremities carefully studied. A description of their innervation follows $:^{26}$

The "aneurogenic" limbs are innervated from three segmental

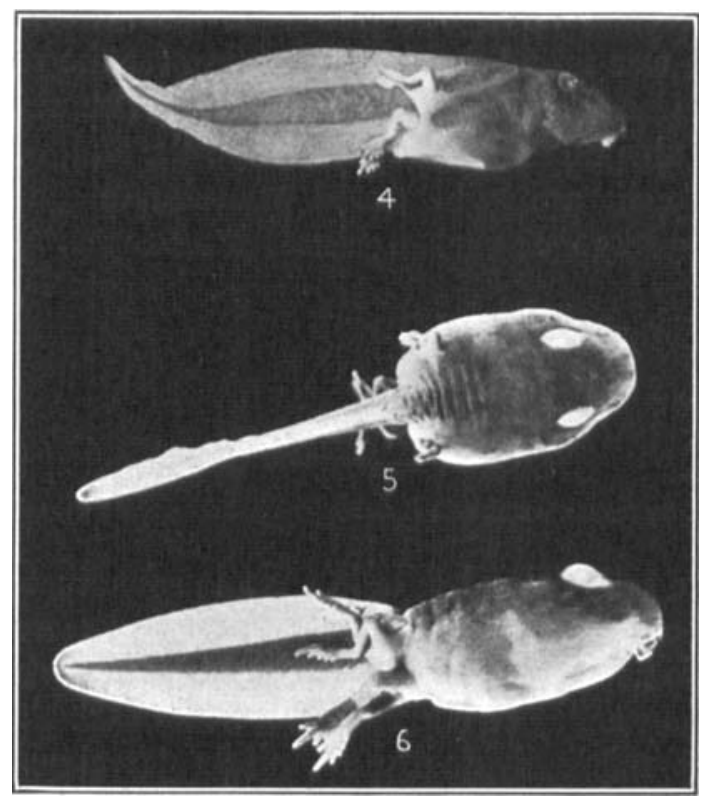

Fig. 4 Subject of Experiment I, showing the "aneurogenic" limbs. $\times 2 \frac{1}{4}$.

Fig. 5 Subject of Experiment III. $\times_{3}$

Fig. 6 Subject of Experiment JI. $x_{3}$.

nerves, the sixth, seventh and eighth. The branch from the sixth is small and does not form anastomoses which are traceable in sections with the others. It runs in the body wall for a considerable distance ventral to the attachment of the limbs, and finally

${ }^{26}$ In this I have been aided by the excellent descriptions given by Gaupp, whose terminology has been followed throughout. 
arches backward again running into the primary limb as its $r$. cutaneus femoris lateralis, a nerve normally derived from the cruralis, which in turn is usually composed of fibers from the eighth and sometimes also the ninth spinal nerves.

The seventh and eighth nerves are large trunks which anastomose freely with one another and it is from this plexus that both the primary and secondary limbs are principally innervated. The arrangement of the plexus is shown in Fig. 7, which was drawn from a graphic reconstruction.

The first nerve to be given off from the plexus is the cruralis,

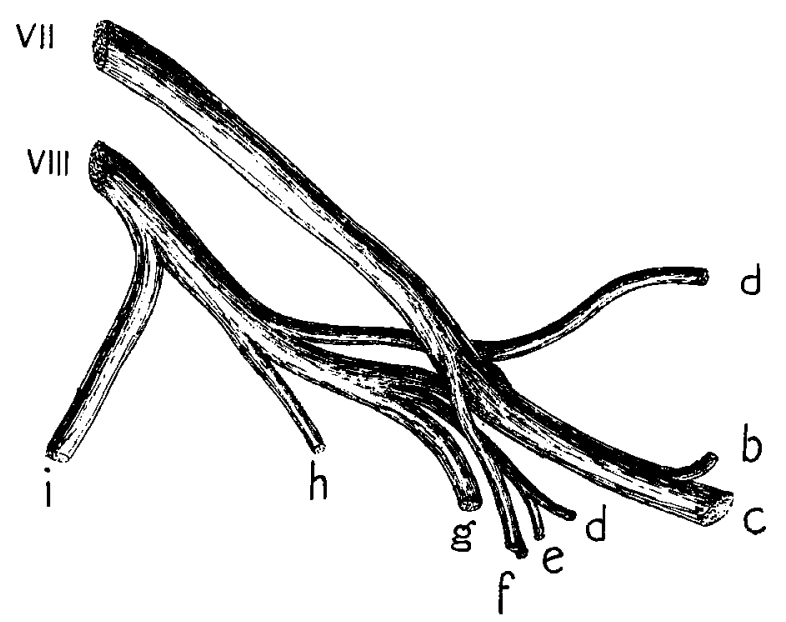

Fig. 7 Plexus from which the "aneurogenic" limbs are innervated, drawn from a graphic reconstruction projected to a horizontal plane. $V I I, \mathrm{r}$. abdominalis $\mathrm{n}$. spinalis VII; $V I I I, \mathrm{r}$. abdominalis $\mathrm{n}$. spinalis VIII; $a, \mathrm{n}$. cruralis of primary limb; $b$, r. profundus posterior; $c, \mathrm{n}$. ischiadicus of the primary $\lim b ; d, r$. cutaneus femoris posterior of the primary limb; $e$ and $f$, rr. accessorii cutanei femoris posteriores of the accessory limb; $g, \mathrm{n}$. ischiadicus of the accessory limb; $h$, n. ilio-hypogastricus of the host; $i$, branch to the plexus lumbo-sacralis of the host. $\times 67$.

which originates from eighth nerve in a stout branch that runs more directly laterally than the main stem. At the point where it crosses the seventh it forms an anastomosis, giving off fibers to the latter, and perhaps, though not certainly receiving fibers from the same. It then runs a short distance anteriorly, arching around the ilium on the surface of the $\mathrm{m}$. iliacus internus (Fig. 8). It gives off a branch to this muscle and then runs distally to the thigh for 
some distance between the $\mathrm{mm}$. adductor longus and pectineus, where it ends.

After giving off the cruralis and several branches to the abdominal walls, the eighth nerve passes abruptly in a lateral direction and intertwines in a complex manner with the seventh. From this

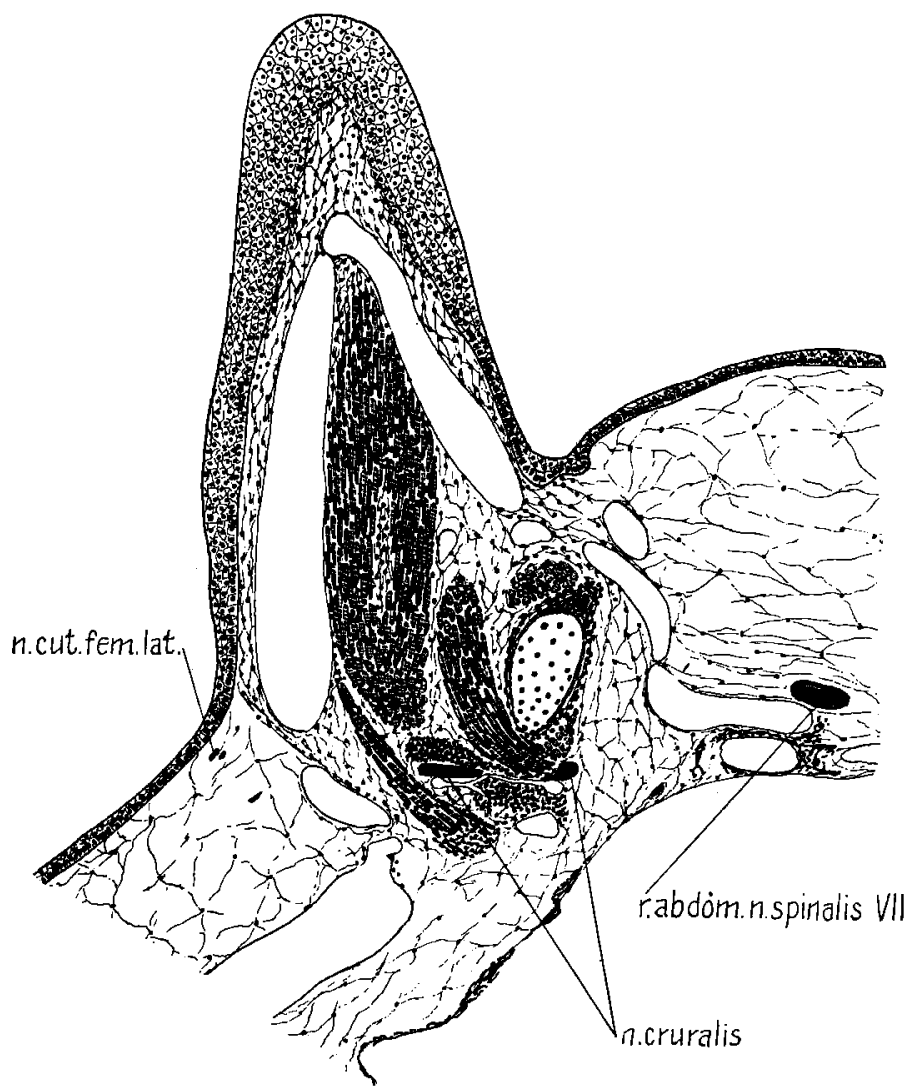

Fig. 8 Experiment I. Section through the thigh of the primary "aneurogenic" leg near the lateral surface, showing the entrance of the $n$. cruralis. $\times 67$.

plexus, the details of which are difficult to make out and to represent in the diagram, a number of nerves are given off. One runs to the secondary limb, becoming its $\mathrm{n}$. ischiadicus (Fig. Io). Three other branches arise separately from the plexus, but before 


\section{Experiments in Transplanting Limbs}

finally dividing, run together only to divide again into a number of branches; several of these run down the thigh of the secondary limb and are distributed to the region over the $\mathrm{m}$. gracilis minor, taking a course which is intermediate between the normal position

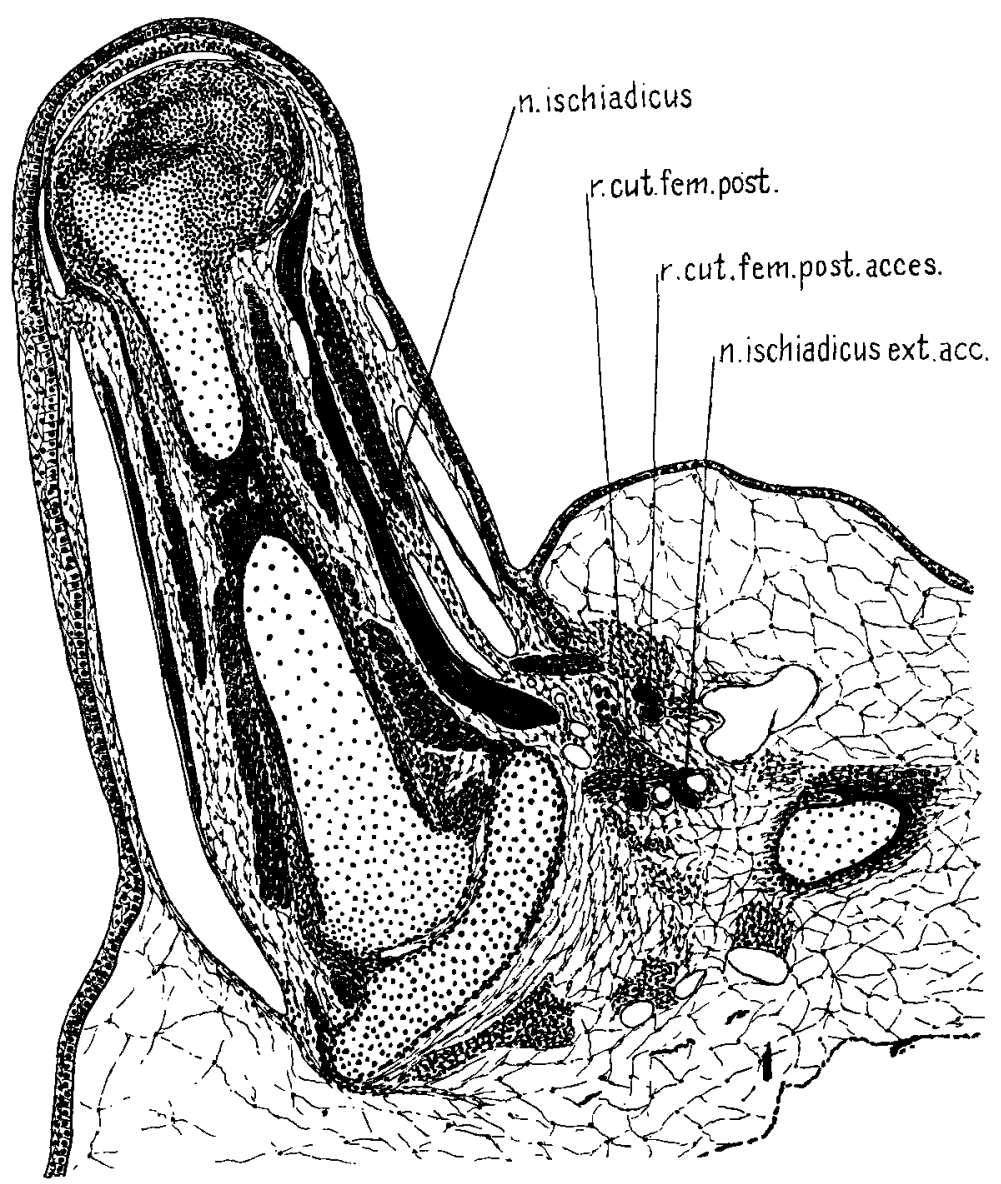

Fig 9 Experiment I. Section through the axis of the thigh of the primary "aneurogenic" limb. r. cut. fem. post. acces., nerves supplying the region of the accessory limb usually innervated by the posterior cutaneous nerve. n. ischiadicus ext. acc., sciatic nerve of accessory limb. $\quad \times 67$.

of the r. cutaneus femoris medialis and r. cutaneus femoris posterior. One of the branches enters the primary limb as the $r$. cutaneus femoris posterior. The largest trunk from the plexus 
becomes the $\mathrm{n}$. ischiadicus of the primary limb, which may readily be followed to the knee in a single section (Fig. 9).

Within the primary limb the nerves may be clearly made out. The large sciatic nerve passes distally parallel to the $\mathrm{m}$. ilio fib-

Primary Limb

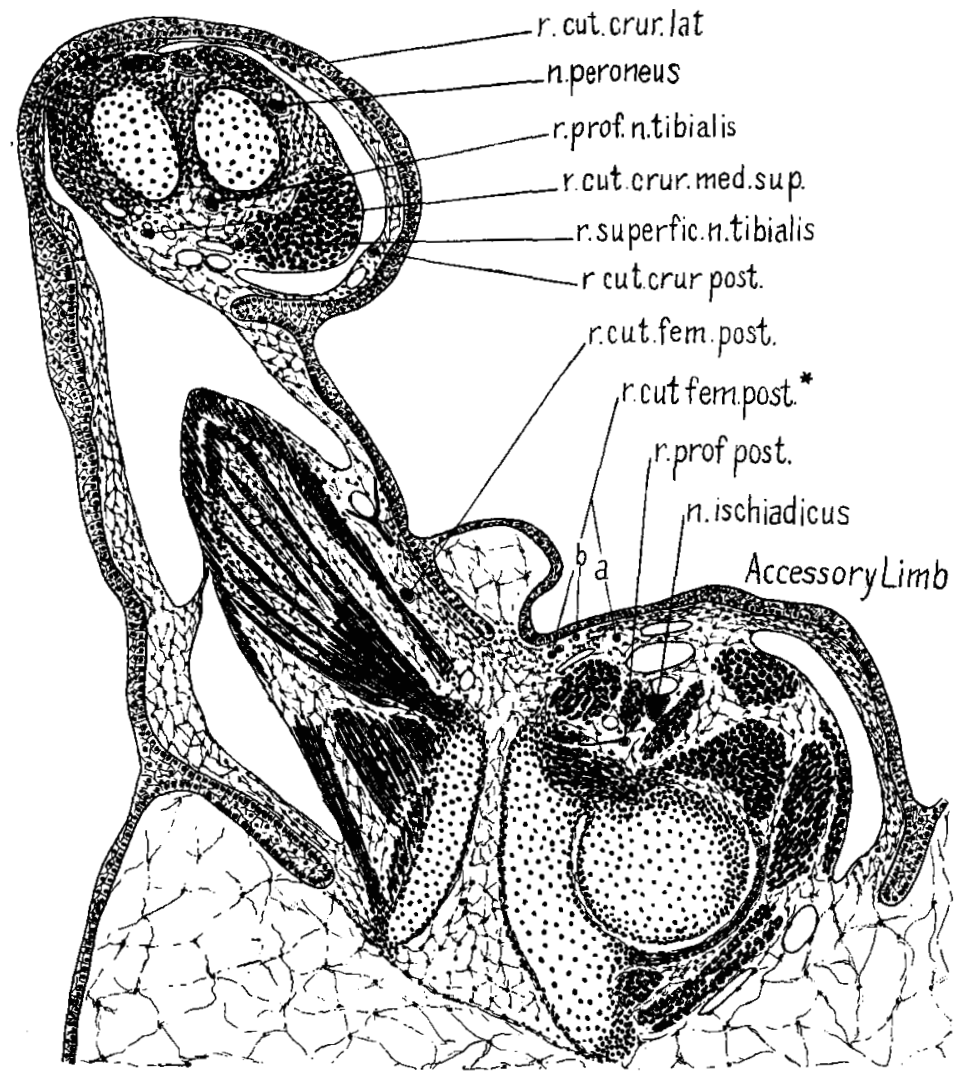

Fig. 10 Experiment I. Section through the thigh of the primary "aneurogenic' limb near the medial surface, showing also the secondary limb cut through the hip joint. $*_{a}$, r. cutaneus femoris posterior, derived from $n$. ischadicus; $b$, accessory nerves derived directly from plexus. $\quad \times 67$.

rilaris and gives off near its beginning the r. profundus femoris posterior. Before reaching the knee it divides into two subdivisions, the n. tibialis and the n. peroneus. The latter gives off a 
nerve which follows the course of the r. cutaneous cruris posterior, a branch which normally comes from the tibial nerve. A little further down the $r$. cutaneus cruris lateralis is given off to the skin (Fig. I0).

Further down in the shank the peroneal nerve divides into a medial and a lateral ramus, the lateral being much the thicker of the two, especially at the point of origin. Lower down the medial ramus becomes stouter and a well defined branch to the $m$. tibialis anticus brevis is shown. The two peroneal nerves pass into the

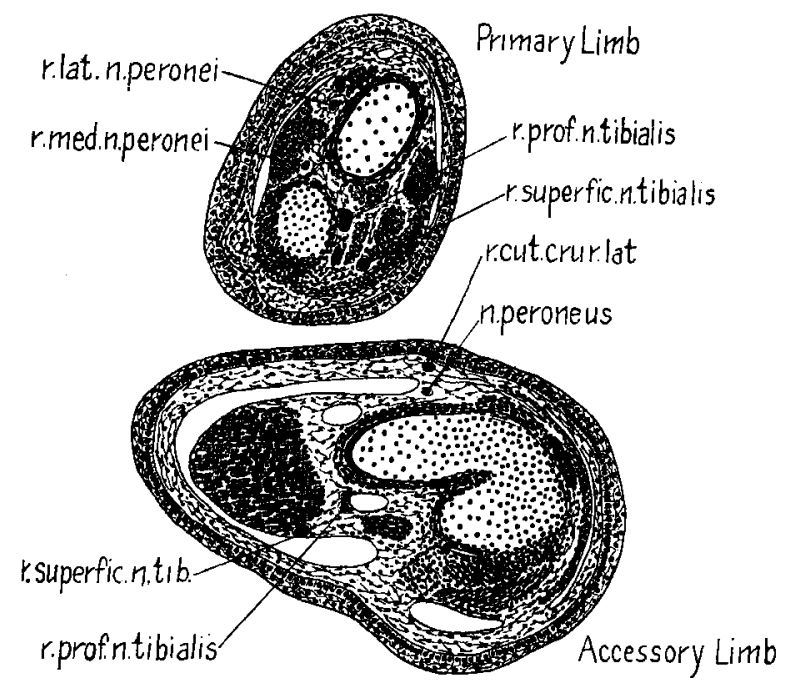

Fig. II Experiment I. Section through the two "aneurogenic" limbs; the primary limb is cut through the tarsus and the accessory limb just below the bnee. $\times 6_{7}$.

tarsal region (Fig. I i). Below the middle of the tarsus they come together again to form the $n$. peroneus communis inferior. Before the dorsum pedis is reached a nerve is given off from this branch which may be traced out into the foot as the n. interstitiales dorsalis primus. In the foot itself the nerve breaks up into two other $\mathrm{nn}$. interstitiales dorsales. One of these interstitial nerves, the third, could not be traced and all the nerves are very fine at this level. It will be seen from the above description that the $n$. peroneus has a normal distribution. The relations to the muscles and other 
structures of the leg are also normal. The only anomaly observed was in the origin of the r. cutaneus cruris posterior.

The distribution of the $\mathbf{n}$. tibialis is also the same as in normal limbs. First the nerve divides into a smaller $r$. superficialis and a larger $r$. profundus (Fig. 10). The latter then gives off a well developed trunk, the $r$. cutaneus cruris medialis superior which may be traced for some distance down the shank. The two rami of the tibial may be followed into the tarsal region and show normal relations to the muscles (Fig. II). The ramus profundus passes into the planta pedis in the proximal part of which it breaks up into the four nn. interstitiales plantares. The manner in which these nerves arise is slightly different from the normal as described by Gaupp (Fig. I2). The r. circumflexus could not be traced.

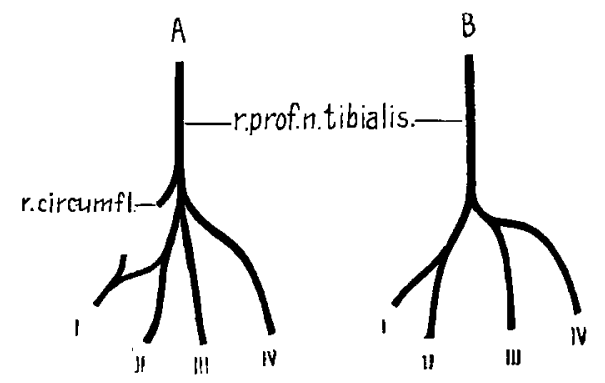

Fig. I2 Diagram of nerve supply to the planta pedis: $A$, according to Gaupp; $B$, as found in the primary "aneurogenic" limb in Experiment I. $I, I I, I I, I V$, nn. interstitiales plantares.

The accessory limb receives from the plexus a much smaller $\mathrm{n}$. ischiadicus than the primary limb (Figs. 9 and Io). In addition to this it receives several short twigs that run subcutaneously along the inner posterior surface of the thigh, supplying an area of skin normally innervated by the $r$. cutaneus femoris posterior and to some extent by the r. cutaneus femoris medialis. The former nerve is small (Fig. Io), and arises in the normal way from the sciatic high up in the thigh. No traces of the $n$. cruralis have been found. The sciatic gives off a distinct though small ramus profundus posterior, though I have been unable to detect a ramus profundus anterior, which normally also arises from the sciatic.

In the lower part of the thigh the sciatic nerve divides as usual 
into the peroneal and tibial nerves. The former gives off at the knee (Fig. II) a ramus cutaneus cruris lateralis and continues down the shank whence it may be followed into the tarsus. This nerve is extremely difficult to follow and it is uncertain whether it divides into its $r$. lateralis and r. medialis. Certain it is that at the tibio-tarsal joint and further on only the $r$. medialis is present. This is, however, quite well defined and may be traced through

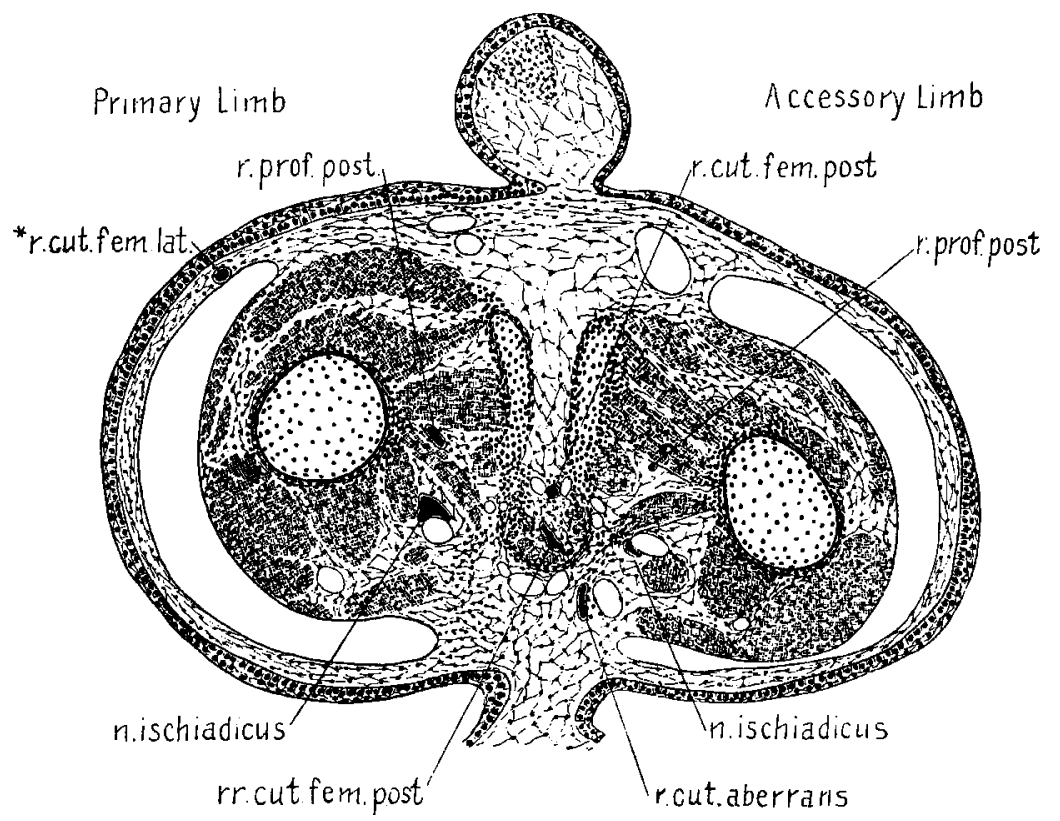

Fig. 13 Section through the two normal transplanted limbs in the upper part of the thigh. * The ramus cutaneus femoris lateralis is some distance from its normal position. $\times 67$.

the tarsal region. I have not been able, however, to make out the $\mathrm{nn}$. interstitiales dorsales.

The tibial nerve, soon after its origin, divides into a superficial and deep ramus of which, contrary to the normal condition, the former is distinctly larger (Fig. II). This may be followed in its normal position through the shank and tarsus into the foot. The deep branch may be followed through the shank. At the tibio-tarsal joint it approaches very near to the superficial branch, 
then it dips behind the tendon of the $\mathrm{m}$. tarsalis posticus and may be followed for some distance through the tarsus. I have been unable to trace it out into the nn. interstitiales plantares.

The normal transplanted, or "euneurogenic" limbs (Fig. 13) receive nerves derived for the most part from the eighth spinal nerve. The seventh gives off a twig to the skin which becomes the $r$. cutaneus femoris lateralis of the primary limb; this nerve is, however, somewhat out of place. The main nerve (from the eighth) runs in between the pelvic cartilages of the primary and accessory limbs in three branches, one of which is considerably larger than the others. This gives rise to the sciatic nerves of the two limbs and to the crural of the secondary. The other two run distally between the pelvic cartilages, and emerge in the skin of the inner side of the two limbs becoming in each the $r$. cutaneus femoris posterior.

Into the primary limb the greater part of the fibers of the main trunk enter as the sciatic, which almost immediately gives off a stout r. profundus posterior which takes its normal course (Fig. 13). The sciatic may be clearly followed to the knee, breaking up into two main divisions, the peroneal and tibial. Below the knee the details of its distribution have not been studied.

The accessory limb receives nerves which are considerably smaller. The crural arises from the main trunk intended for the two limbs before this divides into the two nn. ischiadici. This nerve skirts along the surface of the $\mathrm{m}$. iliacus internus and may be followed as far as the $\mathrm{m}$. pectineus. As the $\mathrm{n}$. ischiadicus, which is smaller than that of the primary limb, enters the accessory limb it gives off an aberrant branch which runs to the skin overlying the $\mathrm{m}$. glutæus magnus. There is no nerve of this size in the normal limb at this place. Higher up, i.e., before the sciatic actually enters the limb it gives rise to a small $r$. profundus posterior which passes ventral to the $\mathrm{m}$. piriformis and may be traced along the dorsal surface of the mm. gemellus and quadratus femoris. It is not nearly so large as the corresponding nerve of the primary limb but it is normally situated with respect to the other structures of the limb.

The sciatic nerve may be followed through the thigh. It divides 
as usual into the peroneal and tibial nerves. The former runs to the skin as the $r$. cutaneus cruris lateralis and I have been unable to find a continuation of the main trunk down the shank. The tibial nerve, as far as can be made out, runs entirely into the r. superficialis, the latter may be traced past the tibio-tarsal joint. In comparing the innervation of the four transplanted extremities in the present case, it is seen that the primary "aneurogenic" limb has the most complete system of nerves, no important nerve being absent. Next in order comes the primary normal transplanted leg, in which, as far as studied, only the n. cruralis is lacking, though there is a nerve which probably represents the r. cutaneus femoris lateralis. The accessory aneurogenic leg is third; it lacks the crural nerve and some branches below the knee; the nerves could not be traced with certainty into the foot. The least complete system of nerves is in the accessory normal transplanted leg, where the sciatic nerve and its branches are much smaller than in the other limbs and no muscular branches are found below the knee. Oddly enough, however, there is a well developed crural nerve in this limb though it is entirely absent from the primary.

Experiment $1 I .{ }^{27}$ For this experiment larvæ of Bufo lentiginosus were used. The procedure differed from the previous case, in that no normal limb was transplanted to the left side. Two nerveless hind limb buds were used; these were taken from a specimen from which the spinal cord had been removed one week before. The first limb transplanted was accidentally pushed through the wound into the body cavity. The second remained attached in the body wall. The larva grew rapidly and was preserved in Tellyesniczky's fluid thirty-five days after transplantation of the limb. As is readily seen in Fig. 6, the second of the transplanted buds has developed into a pair of hind legs, which are connected with the body by a short narrow stalk. Dorsal to these two legs, which are normally formed, there is an irregular mass, which sections show to have developed out of the bud that was pushed into the peritoneal cavity. Two hind legs are distinguishable in this mass but they are very irregularly developed 
and the sections are almost impossible to interpret. The description will therefore be confined to the other pair. While these limbs are further advanced in development than those in the previous experiment, it was apparent from the observation of the living specimen that they were not so well formed. They had a slightly atrophic appearance and were never seen to undergo even the slight twitching movements observed in the first experiment.

Sections show that a small nerve trunk, which arises from the eighth spinal nerve of the host enters the stalk which connects the limbs with the abdominal wall, and running between the two pelvic cartilages, is continued into the accessory or super-regenerated limb. This is all the more remarkable because no nerves could be traced into the primary limb. The nerve in the accessory leg follows the course normally taken by the $\mathrm{n}$. ischiadicus. Above the knee joint it divides into two trunks, one running to the flexor and one to the extensor surface of the shank. Both of these are cutaneous nerves and correspond respectively in distribution to the $r$. cutaneus cruris posterior, which arises normally from the n. tibialis, and to the r. cutaneus cruris lateralis derived normally from the n. peroneus. No muscular nerves can be made out below the knee.

The imperfect innervation of the limbs in this case as compared with the previous one is due no doubt to less firm implantation into the tissues of the host.

Experiment $I I I .^{28}$ In this case a hind limb bud taken from a normal larva (Bufo lentiginosus) was implanted in the left side and one taken from a nerveless larva on the right. The spinal cord of the latter had been excised one week before.

Both limbs developed well and produced accessory limbs. The normal bud on the left produced a typical limb scarcely distinguishable from the primary. The nerveless limb produced an imperfect appendage, which in turn bore an accessory bud. The specimen was preserved forty days after the operation (Fig. 5).

The limbs derived from the normal transplanted bud receive a large nerve from the seventh spinal nerve of the host. Two

${ }^{2 s}$ Record number, Tr. Ext. 12. 
small branches are given off to supply the primary limb. One follows the sciatic artery a short distance down the thigh, and is to be regarded as a rudimentary $n$. ischiadicus. The other runs to the skin of the thigh and corresponds in position to the $r$. cutaneus femoris lateralis. The secondary limb receives a much larger bundle of fibers. These run into a large $n$. ischiadicus, which however ends before it reaches the knee. It gives off in the upper part of the thigh a distinct $r$. profundus posterior.

The limbs derived from the nerveless bud also contain nerves. A branch from the seventh spinal nerve supplies them. This nerve runs first as a compact bundle. Just before passing the pelvic cartilage it becomes frayed out to some extent, but may nevertheless be followed nearly to the knee, giving off a r. profundus posterior.

The secondary limb is much less advanced in development than the primary but it receives a large branch of the above mentioned nerve, which runs into the thigh for a short distance in the position of the $n$. ischiadicus.

In this case, as is readily seen from the figure, all. four of the transplanted limbs are considerably less advanced in development than in the first case described. It is possible that had the larva been kept alive for a longer time, the nervous system of the limbs would have become more complete. It is worthy of note that in this case the primary normal leg has the least complete innervation of all the four transplanted appendages.

Experiment $I V .{ }^{29}$ This experiment, made upon Rana larvæ, differed from the others in that the limbs were transplanted to the back immediately behind the anterior lymph hearts. As before, a normal left bud was placed on the left side and a nerveless right on the right. The larva from which the latter was taken had lived nine days after extirpation of its spinal cord. Sections of this larva show that there are no nerves posterior to the vagus, the funicular fibers not even having grown out from the brain. The yolk is entirely absorbed except for a few granules in the intestinal epithelium.

${ }^{20}$ Record number, Tr. Ext. I I. 
Each bud developed into but a single appendage, and neither of these were so far advanced in development as the limbs in the other cases described. Twenty-six days after the transplantation the specimen was preserved and afterward examined in sections. Both of the transplanted legs are innervated principally by the $r$. lateralis vagi. In the case of the normal transplanted limb on the left side a branch is given off from this nerve, which after skirting along a large vesicle, formed from the transplanted tissue, finally enters the thigh. Here it may be followed for some distance as the $\mathrm{n}$. ischiadicus. In addition to this nerve a small branch from one of the spinal nerves extends out along the lateral surface of the thigh in the region normally supplied by the $r$. cutaneus femoris lateralis.

In the nerveless transplanted limb, which is cut more favorably than the other, the $\mathrm{n}$. ischiadicus formed by the lateralis vagi may be readily traced to the knee. In this region it divides, one branch running to the skin where it may be followed some distance further. The other ultimately becomes lost in the mesenchyme. No traces of lateral line sense organs in the leg could be found. There are irregularities in the development of the cartilages in this limb and the muscles are scarcely differentiated at all so that the topographical relations are to some extent uncertain.

In comparing the above experiments it is seen that with a single exception all of the transplanted limbs contain nerves. There are great individual differences as regards completeness of innervation but in this respect the corresponding limbs in the different experiments do not occupy the same relative position. These features are expressed in the accompanying table. From this it is clear that the limbs which have been taken from nerveless individuals have fared rather better as regards innervation than the normal transplanted limbs have, and also that while the accessory limbs are less completely innervated in three cases, they are more completely innervated in two.

The most constant nerve is the ischiadicus, and as might be expected the proximal regions of the transplanted limbs are the most completely supplied. In general the cutaneous nerves are 
more fully represented than the muscular. With regard to the former it may be pointed out that some variations in position and origin have been observed. These have been noted in both the "aneurogenic" and normal limbs and in the primary as well as in the secondary. It follows that we cannot discriminate between the different types of limb as regards their ability to acquire a normal nervous system.

Table showing the relative completeness of innervation of the limbs in the individual cases.

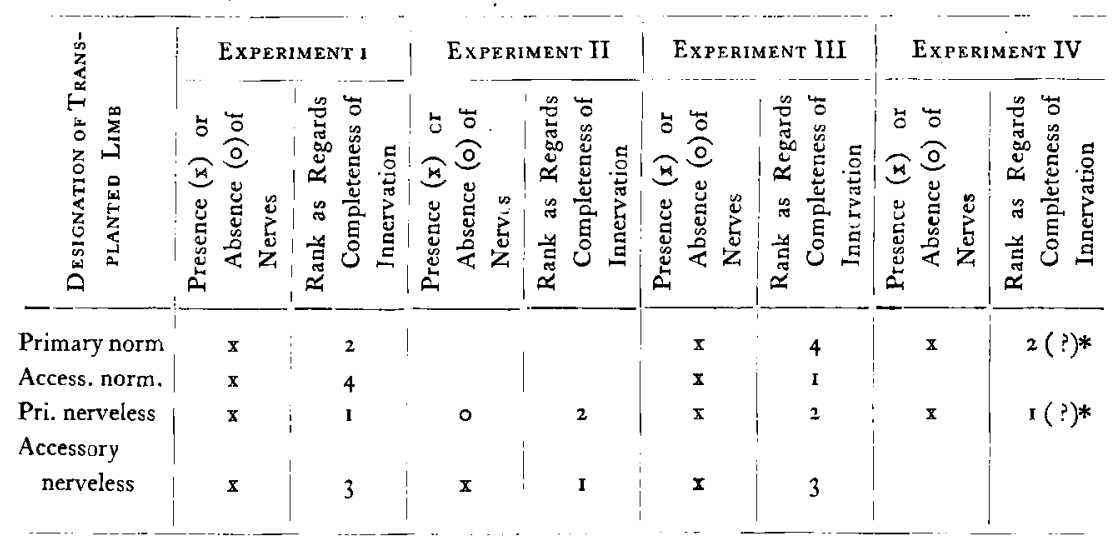

* It is uncertain which of these should be regarded as the mure completely innervated.

\section{Transplantation of Normal Limbs to Nerveless Regions}

The object of the following experiments was to test the power of peripheral nerve fibers to develop when entirely cut off from nervous connection with the centers. It has already been shown that both Braus and Banchi have failed to establish their claim that the nerves have this power, for in their experiments the nerves studied were contained in appendages that were implanted into regions where numerous nerves were present. The only crucial test of this question by means of the method of transplantation is to graft tissues containing developing nerves to the body of an individual in which nerves are entirely lacking, or at least to an extensive nerveless region.

While no difficulty has been encountered in obtaining tadpoles with extensive nerveless regions, it has heretofore been found 
impossible to keep such specimens alive after the yolk is gone. Even when the brain and cranial ganglia are left intact so as not to interfere with the normal movements of the mouth parts and gills, the larva soon succumb, owing to their inability to move about and obtain food. During the course of my experiments in the spring of 1906 a method was devised for providing the cordless, and therefore paralyzed, larvæ with nurses. This is accomplished in the following manner: We start with embryos about $3 \mathrm{~mm}$. in length, in which no nerves are as yet differentiated. After removal of the entire medullary cord caudal to the vagus region, a small piece is cut off the side of the belly of the embryo and a similar piece is taken from the opposite side of a normal embryo. The wound surfaces of the two embryos are then brought together and the embryos are held in place for an hour by means of pieces of silver wire, as described by Born, after which time they are permanently united. The further development of the pair takes place normally except as regards the direct effect of the wound healing, which brings about the formation of intestinal and vascular anastomoses between the two. In this way the normal component, which moves about and obtains food, is able to sustain the pair for some time. When the yolk is about absorbed the experiment is completed by transplanting to the nerveless component a limb bud taken from a normal larva of the same age or a little older. Such limbs contain, as already described, ${ }^{30}$ the terminal twigs of nerves. The limb is grafted to the posterior part of the trunk a little dorsal and cranial to the natural hind limb, and in all cases was put on the free side of the body, i.e., the side away from the nurse. The trunk region of the larva remains nerveless except that the $r$. lateralis vagi is present. There may be some extension of fibers from the nurse into the tissues of the nerveless component immediately adjoining the former, but only in one instance has a nerve been observed passing from the normal component to the opposite side of the other. This nerve passed under the notochord of the nerveless component after giving off twigs to the axial musculature and finally ended in the skin 
of the opposite side some little distance from the transplanted limb. While it is necessary, therefore, to guard against contamination even in these experiments, still in all the cases but this one there is a very extensive nerveless region and the limb which is transplanted to this is far removed from the source of extrinsic nerves.

The outcome of these experiments was not altogether satisfactory because the limbs transplanted to the nerveless in dividuals in no case developed rapidly and hence even after the expiration of three weeks or more they are nothing more than mere knobs (Fig. 14). The natural hind limbs of these specimens are like-

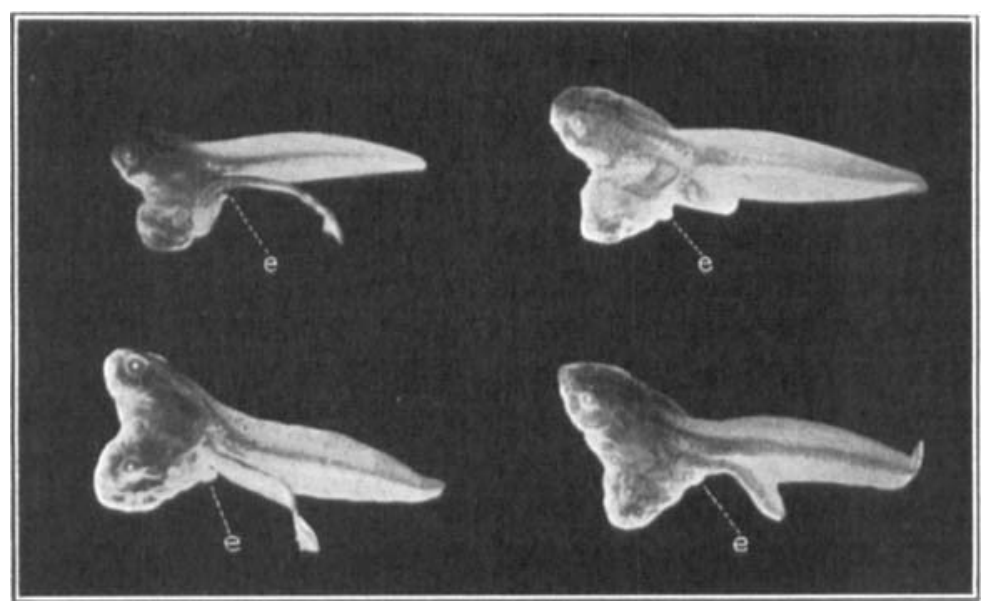

Fig. 14 Four nerveless larva, attached to normal nurses. e, transplanted extremity. $\times 2$.

wise poorly developed and it seems probable that the nutrition is insufficient to provide for a normal rate of growth. By modification of the method, I hope during the present season to obtain more conclusive results.

It will not be necessary to describe the individual experiments in great detail. Seven cases have been examined in all. The specimens were preserved two, three, five, seven, ten, twelve and fifteen days, respectively, after transplantation of the limb. In four of these no traces whatever of nerves could be found in the transplanted limbs or anywhere near them, although at the time 
of transplantation the limbs did contain fine nerve twigs. The three specimens that do contain traces of nerves are those which were preserved two, seven and ten days, respectively, after the operation. In the first of these there is a short twig present which contains several Schwann cells and fibrillix in a state of disintegration. The same is true of the ten-day specimen. In the sevenday specimen considerably more than the usual amount of tissue had been transplanted and this included part of several myotomes; hence this experiment is directly comparable to those of Banchi. In the transplanted tissue several structures are to be found which are undoubtedly degenerating nerves. One of these is a chain of cells without any visible fibrillæ; the others show fibrillæ in addition to the cells, though the former are indistinct.

The results of these experiments plainly indicate that there is no progressive development of the nerve after severance of its connection with the center. On the contrary there are rapid regressive changes, which in the majority of cases result in the entire disappearance of the nerves within a few days after they are cut off from their centers. The one case, in which the larger trunks were transplanted and which showed definite traces of the transplanted nerves after the expiration of ten days, may be taken as indicating that larger nerves will persist longer than the finer terminal twigs.

Two other series of experiments have been made for the purpose of testing in a more simple manner, the direct effect of the removal of the ganglion cell upon the growing nerve fiber. It was found that excision of the spinal cord in embryos of Rana palustris $8.5 \mathrm{~mm}$. long results in the complete disappearance of the motor rami after a few days, and likewise the removal of the vagus ganglion in embryos $6 \mathrm{~mm}$. long brings about rapid disintegration and early disappearance of the r. lateralis. ${ }^{31}$ In these experiments sources of contamination from anastomoses were under control. The results are in entire accord with the results of transplantation of limbs just described, and they show that a

${ }^{31}$ These experiments were made in collaboration with Mr. Laurence Selling, who will report upon them Jater in full. 
young developing nerve which has been deprived of its ganglion is doomed to early disintegration.

\section{CONCLUSION}

The immediate result of the experiments in transplanting extremity buds to normal individuals is to show that, as far as the acquisition of a normal peripheral nervous system is concerned, it is quite immaterial whether the bud, prior to its transplantation, has developed in connection with the central nervous system or not. It is likewise shown to be of no consequence, as regards its nerve supply, whether a limb develops directly out of the transplanted bud or whether it arises later as an accessory or superregenerated appendage. These facts are in direct contradiction to the premises upon which Braus bases his support of Hensen's theory. The whole superstructure of his argument therefore falls to the ground, and it will be necessary to build entirely anew in inquiring into the bearing of the experiments upon the problems of the development of nerves.

It is clear that the experiments do not kear directly enough upon the point to decide satisfactorily questions of histogenesis, though they do throw important light upon the manner in which the peripheral distribution of the nerves is brought about. The original experiment of Braus, confirmed in the present study, shows that a normal limb bud, when transplanted to practically any region of the body of a normal tadpole, will acquire a system of peripheral nerves, which do not differ appreciably from the normal in their arrangement, and which are connected with the nerves of the region into which the limb is implanted, although in normal individuals the latter nerves may have no relation whatever with the limbs. This fact, though in other respects of cardinal importance, affords no solution of our problem because it may be interpreted in accordance with either the primary continuity or the outgrowth theories; either the nerves arise in situ out of structures present within the limb at the time of transplantation, or they grow in from the nerves of the host and are guided to their proper places of termination by the other structures within the limb. 
Experiments which have already been reported by Lewis and by myself ${ }^{32}$ are sufficient to decide in favor of the latter alternative. Destroy the nerve centers of an embryo no nerves ever develop. Transplant the centers containing ganglion cells to otherwise sterile (nerveless) regions, nerves will develop radiating from them, often following paths entirely unknown as nerve paths in the normal organism; in one case even the peritoneal cavity was bridged. Alter in the most profound manner the path normally taken by certain nerve fibers, at the same time leaving the nerve centers intact, fibers will, nevertheless, develop in connection with the center, following the normal direction of growth, though in strange surroundings. Again, ${ }^{33}$ if the ganglion cells are removed after the nerves are partially developed, further development ceases and all traces of the nerve may entirely disappear; but on the other hand, as is well known, if the nerve is removed leaving the center intact, a new nerve is soon formed in its place. These facts show that the first essential for the formation of the nerve fiber is the ganglion cell. The only other condition, which, as far as known at the present time, is necessary, is that there must be a surrounding medium in the form of living tissue. There is no evidence, however, that any specifically formed or localized structures, essertial to the formation of nerve fibers, are present within this medium. ${ }^{34}$

Hensen's theory supposes that the protoplasmic bridges connecting the various cells of the embryonic body, play this part.

${ }^{32}$ Harrison 'o6; Lewis 'o6.

${ }^{33}$ See p. 272.

${ }^{34}$ Recently Held has maintained, in accordance with Hensen's theory, that the outgrowth of the nerve fiber from the ganglion cell is only apparent and in reality is but a differentiation of preëxisting protoplasmic filaments found between the various organs in the embryo. "Entsteht also die Nervenleitung durch die Umwandlung von Plasmodesmen in Neurodesmen" (op. cit., p. 188). A full discussion of this work will be deferred to a future communication dealing more especially with histogenesis. It may, however, be pointed out here that it is by no means certain that the plasmodesms are not artefacts-products of coagulation (cf. Harrison, Arch. f. mikr. Anat., Bd. 57, p. 42I, and v. Lenhossék, Neurologisches Centralblatt, Bd. 26, p. 127). Nor can it be certain in consideration of the extreme minuteness of the structures in question, whether the fine filaments of the nerve process actually run into the fine protoplasmic threads or along them. At least it is very siginficant to find that Ramon $y$ Cajal ('o7), employing methods essentially similar to those of Held, nevertheless gives his full support to the outgrowth view. 
Coming from a physiologist, the especial virtue of the theory, as might be expected, is physiological; it places the genesis of the permanent nerve paths upon the basis of functional adaptation; of all the numerous undifferentiated protoplasmic connections existing in the embryonic body, it is only those which function in conducting impulses that persist as permanent nerves; the remainder atrophy from disease. In refutation of this hypothesis it may be pointed out, however, that the functional activity of a nerve has no appreciable influence at least upon its early development. Amphibian embryos reared in a solution of acetone chloroform ${ }^{35}$ acquire a perfectly formed nervous system, and one capable of normal functional activity, though during the whole period of their development up to the stage when the yolk is entirely absorbed, at which time the peripheral nerves are all well differentiated, no functional activity of the nervous system is manifested. Furthermore, in the transplantation experiments just referred to, a number of nerves were formed to which no conceivable function could be assigned, as, for instance, the funicular fibers which, after the removal of the medullary cord of the trunk, extend out from the brain and lose themselves in the mesenchyme.

It is precisely in this connection that the experiments in transplanting nerveless limbs are of great significance. A nerveless limb is taken from an organism that has undergone the greater part of its development after having been deprived of its spinal cord. As a consequence, no nerves are developed in the trunk region, and there is no evidence of nervous activity there, although in a normal individual during the same period, all of the important nerves, including those running to the extremities are visibly differentiated and for the most part are functioning. It cannot be supposed that the pre-nervous protoplasmic bridges, postulated by Hensen's theory, would be able to survive this long period of disuse, for, as experiments show, even visibly differentiated nerve fibers degenerate very rapidly after removal of their centers, often disappearing without leaving a trace in a much shorter time than that during which the nerveless individuals in question have been

${ }^{35} \mathrm{H}$ arrison ${ }^{\circ}{ }_{4}$. 
without their spinal cords. And yet when the limb of such an individual is transplanted to a normal larva it acquires a complete and normally arranged system of peripheral nerves just as a $\operatorname{limb}$ taken from a normal larva does. In other words, lack of functional activity, consequent upon the absence of nerve centers during a protracted and important period of development, does not in the least interfere with the later normal development of the nerves as soon as new nerve centers are supplied. These nerves, therefore, must be regarded as the product of the nerve centers alone.

This answer to the question being firmly established as correct, the cardinal importance of Braus' fundamental experiment becomes apparent, for, contrary to the conclusion drawn by its author, it shows that the structures contained within the limb must have a very important directive action upon the developing nerve fibers, in that they determine their mode of distribution. The manner of branching cannot possibly be predetermined in the ingrowing nerves themselves, because in the normal body these same nerves have an entirely different distribution. Let us picture to ourselves what probably takes place after a limb is transplanted. It is put into a region well supplied with nerves. The wound made for the reception of the bud involves without fail injuries to the nerves of the region. This stimulates the fibers to grow and in so doing some of them will come into contact with the cells of the transplanted bud, which at that time consists of a blastema of mesenchyme cells covered by epidermis but not visibly differentiated. As the bud grows into a leg and the blastema differentiates, the nerve fibers become arranged and segregated according as they are attached to the organs within the limb. In the limbs in normal position the development of the nerves must go on in the same way. Here too the nerve fibers reach the bud when it is still without visible differentiation. Contact with the cells contained within it being made at that time, the peripheral branches of the nerves are determined as the constituent parts of the limbs are segregated. The fact that any nerve in whose way a limb is planted is capable of giving rise to intrinsic nerves having perfectly normal arrangement, shows that the nerves themselves must be guided in the formation of their terminal ramifications. 
This interpretation is in accordance with Nussbaum's law that the course of the nerve within the muscle is an index of the direction in which the muscle has grown. ${ }^{36}$ In other words, the original point of contact between nerve and muscle persists as the entrance point of the nerve after growth is completed.

It is only necessary to suppose that action takes place at very short distances in bringing about first contact between the developing nerve fibers and the cells of the limb bud. Failure on the part of Hensen and the later advocates of his theory to realize this, has led to the great magnification of the difficulties which an outgrowing fiber would supposedly encounter in reaching its proper end organ. It is not necessary to imagine, as a number of writers do, that the growing nerve would have to wend its way through a labyrinth of differentiated tissues, extending from the hip to the toes, in order to reach its end organ, but merely that the nerve must grow independently as far as the base of the undifferentiated limb bud, the rest being provided by the development of the limb itself. The above interpretation calls nothing mysterious, nothing hypothetical into play. It is based solely upon known facts and does not postulate the existence of invisible and otherwise unknown structures. It is the only explanation that can be accepted in the present state of our knowledge. Moreover the variations in the distribution of nerves within normal limbs and especially the slight aberrations from the normal which have been noted in the position of some of the nerves in the transplanted limbs meet a ready explanation on this basis.

The foregoing suggests the consideration of certain meristic variations in peripheral nerves. ${ }^{37}$ It has long been known, having been pointed out especially by Fürbringer, that the nerve plexus from which a limb is supplied might in two cases have a different metameric origin, and yet the nerves arising from the plexus might be distributed in the same manner in each. Gegenbaur, who, like Fürbringer, held closely to the theory that muscle and nerve form an inseparable unit, admitted the difficulty of satis-

\footnotetext{
${ }^{38}$ Nussbaum '94.

${ }^{37}$ This matter was brought up by Dr. McMurrich and Dr. Bardeen during the discussion of my paper at the Toronto Meeting, and has been fully discussed very recently by the latter (Bardeen 'o 7 ).
} 
factorily explaining such variations..$^{38}$ The interpretation of the transplantation experiments just given avoids this difficulty, for it brings out the fact that there are two main determining factors in the development of the innervation of a limb. The first of these is the position and extent of the extremity at the time of origin; this determines the source of the nerve supply. The second factor is the mode of segregation and growth of the individual structures of the limb, which determines the intrinsic distribution of its nerves. The experiments show that these two factors may be varied independently of one another. Variations in the position and extent of the rudiment of a limb, which may be assumed to occur frequently in nature, will, therefore, result in the ingrowth of different metameric nerves, and still the intrinsic distribution of their branches may remain constant, owing to the circumstance that the factors determining the latter operate in the same way regardless of the source of the nerves upon which they have to act. Both individual variations and specific differences in the metameric origin of limb-plexuses are naturally explained in this way.

\section{SUMMARY}

I Limb buds of tadpoles, when transplanted to various parts of the body of normal individuals, develop normally and acquire usually a complete or partially complete system of peripheral nerves, which have normal arrangement and are connected with the nerves of the host supplying the region in which the limb is implanted.

2 The whole trunk region of an embryo may be made "nerveless" by cutting out the medullary cord posterior to the ear vesicle, just after closure of the medullary folds. Limb buds taken from such individuals and transplanted to normal larvæ behave exactly like the normal limb buds as regards the acquirement of nerves.

3 Accessory limbs, which frequently develop from transplanted buds by a process of super-regeneration, receive nerves either directly from the host or from nerve trunks running to the primary transplanted extremity. Sometimes the innervation of the acces-

${ }^{336}$ Die metamere Umbildung, wie sie sich als Verschiebung zeigt, bleibt damit ein Problem, dessen Lösung man sich vorläufig nur mittels der Hypothese nähern kann." Gegenbaur, op. cit., p. 6ı3 
sory limb is more complete than that of the primary, though more frequently the reverse is the case.

4. It is possible to keep a nerveless larva alive for a period of a month by grafting it to a normal larva, which acts as a nurse. When a normal extremity bud is transplanted to such a nerveless larva, the nerve twigs contained within the former soon degenerate and no signs of progressive development of the nerves in such cases are to be observed. There is no evidence that an embryonic nerve can continue its development after its connection with the center is severed and prevented from being re-established. Cases which have been reported to the contrary are to be attributed to the presence of anastomoses.

5 The nerves are not formed in situ in the transplanted limbs but grow into them from the nerves of the host. Experiments which have previously been reported permit of no other conclusion and this is strongly reinforced by the experiments with nerveless limbs. Hensen's theory of primary continuity between nerve center and end organ is untenable, nor does functional activity play any part in the early development of the nerve paths.

6 Nerves reach the limbs, both natural and transplanted, when the limbs are in the earliest stages of their development and are composed of an undifferentiated blastema of mesenchyme cells. The intrinsic distribution of the nerves is determined by the structures within the limb, most probably at the time when the cells of the blastema segregate into the various definitive structures. This follows necessarily from the fact that any nerve which is led to enter the limb will assume the normal arrangement for that limb.

7 There are thus two important factors determining the innervation of a limb: First, its position and extent at the time of origin; upon this the source of nerve supply depends. Second, the structures within the limb itself; these fix the mode of distribution of the nerves.

8 These two factors are entirely independent of one another. Meristic differences in nerve supply of limbs, either between individuals or between species, which may exist without affecting the intrinsic distribution of the nerves, are to be regarded simply as due to variations in the original position and extent of the limb rudiments. 


\section{REFERENCES}

Banchi, Arturo, '04-Sviluppo degli arti addominali del Bufo vulgaris innestati in sede anomala. Monitore Zoologico Italiano, Anno I5.

'05-Sviluppo degli arti pelvici del Bufo vulgaris innestati in sede anomala. Arch. di Anat. e di Embriol. Vol. 4.

'o6-Sullo sviluppo dei nervi periferici in maniera independente dal sistema nervoso centrale. Anatom. Anzeiger. Bd, 28.

Bardeen, Charles R., '07-Development and Variation of the Nerves and the Musculature of the Inferior Extremity and of the Neighboring Regions of the Trunk in Man. American Journ. Anat., Vol, vi.

BARFURTH, D., '94--Die experimentelle Regeneration überschüssiger Gliedmassenteile bei den Amphibien (Polydaktylie). Archiv f. Entwickelungsmechanik. Vol. I.

Braus, Hermann, 'O3-Versuch einfr Experimentellen Morphologie. Naturhistorisch-Medicinischer Verein Heidelberg. (Medizin. Sekt.) Sitzung vom 17 Nov. Münchener medizinische Wochenschrift.

'04-Einige Ergebnisse der Transplantation von Organanlagen bei Bombinatorlarven. Verhandlungen der Anatomischen Gesellscha f́t. I8. Versammlung in Jena.

'05-Experimentelle Beiträge zur Frage nach der Entwickelung peripherer Nerven. Anatom. Anzeiger, Bd. 26.

Cajal, S. Ramon y, 'o6-Studien über die Hinrinde des Menschen. 5 Heft. Leipzig. (Cited from Schiefferdecker.)

'o7-Die histogenetischen Beweise der Neuronentheorie von His und Forel. Anatom. Anzeiger, Bd. 30 .

Dogrel, A., 'o4-Ueber die Nervenendigungen in den Grandryschen und Herbst schen Körperchen im Zusammenhange mit der Frage der Neuronentheorie. Anatomischer Anzeiger. Bd. 25.

Forssman, J., '98-Ueber die Ursachen welche die Wachstumsrichtung der peripheren Nervenfasern bei der Regeneration bestimmen. Ziegler's Beiträge zur patholog. Anat. u. zur allgem. Pathologie, Bd. 24.

'oo-Zur Kenntniss des Neurotropismus. Ibid. Bd. 27.

Fritsch, Gustav, '87-Die elektrischen Fische. I. Abtheilung. Malapterurus electricus. Leipzig.

Fürbringer, Max, '79-Zur Lehre von den Umbildungen der Nervenplexus. Morphol. Jahrb. Bd. 5

Gaupp, Ernst, '96-'99-A. Ecker's and R. Wiedersheim's Anatomie des Frosches. Erste und zweite Abteilungen. Dritte Anflage. Braunschweig. 
Gegenbaur, Carr, '98-Vergleichende Anatomie der Wirbelthiere. I. Band. Leipzig.

Gemelli, Fra Agostino, 'o6-Ricerche sperimentali sullo sviluppo dei nervi degli arti pelvici di Bufo vulgaris innestati in sede anomala. Revista di Pathologia Nervosa e Mentale. Anno i r.

Harrison, Ross Granville, 'O3-Experimentelle Untersuchungen über die Entwicklung der Sinnesorgane der Seitenlinie bei den Amphibien. Arch. f. mikr. Anat. Bd. 63 .

'04.-An Experimental Study of the Relation of the Nervous System to the Developing Musculature in the Embryo of the Frog. American Journ. Anat. Vol. 3 .

'o4a-Neue Versuche und Beobachtungen über die Entwicklung der peripheren Nerven der Wirbeltiere. Sitzungsber. der Niederrheinischen Gesellsch. f. Natur u. Heilkunde zu Bonn. Sitzung I I. Juli.

'05-Further Experiments on the Development of Peripheral Nerves. American Journ. Anat. Vol. 5 .

Held, Hans, 'o6-Zur Histogenese der Nervenleitung. Verhandlungen der Anatomischen Gesellschaft. 20. Versammlung in Rostock.

Hensen, V., '64-Ueber die Entwickelung des Gewebes und der Nerven im Schwanze der Froschlarve. Virchow's Archiv. Bd. 3 I.

68-Ueber die Nerven im Schwanz der Froschlarven. Archivf. mikr. Anat. Bd. 4.

'03-Die Entwickelungsmechanik der Nervenbahnen im Embryo der Säugetiere. Kiel und Leipzig.

Lewis, Warren Harmon, 'o6-Experimental Evidence in Support of the Outgrowth Theory of the Axis Cylinder. Proc. Assoc. Am. Anat. Am. Journ. Anat. Vol. V.

Nussbacm, M., '94-Nerv und Muskel: Abhängigkeit des Muskelwachstums vom Nervenverlauf. Verhandlungen der Anatomischen Gesellschaft. 8. Versammlung in Strassburg.

Retzius, Gustaf, '05-Punktsubstanz, "Nervöses Grau" und Neuronenlehre. Biol. Unterscuhungen, N. F., Bd. I2.

Schiefferdecker, P., 'o6-Ueber das Verhalten der Fibrillen des Achsenzylinders an den Ranvierschen Einsuchnürungen der markhaltigen Nervenfasern. Archiv f. mikr. Anat. Bd. 67.

'o6a-Neurone und Neuronenbahnen. Leipzig.

Tornier, Gustav, '05-An Knoblauchskröten experimentell entstandene überzählige Hintergliedmassen. Archiv f. Entwickelungsmechanik. Bd. 20. 